\title{
Tuberculous epididymo-orchitis masquerading as acute scrotum
}

\author{
Ned Kinnear, ${ }^{1}$ Ivan Hoh, ${ }^{2}$ Pedro Campillo, ${ }^{2}$ John Bolt ${ }^{2}$
}

${ }^{1}$ Department of General Surgery, Lyell McEwin Hospital, Elizabeth Vale, South Australia, Australia

${ }^{2}$ Department of Urology, Royal Adelaide Hospital, Adelaide, South Australia, Australia

\section{Correspondence to}

Dr Ned Kinnear,

ned.kinnear@gmail.com

Accepted 13 January 2016

\section{SUMMARY}

An 18-year-old boy, a refugee from Afghanistan, with no significant medical history, presented after 1 day of severe left testicular pain. History, clinical examination and scrotal ultrasound suggested the diagnosis of epididymo-orchitis. He was discharged on a 2-week course of amoxicillin/clavulanic acid. Six weeks later, he re-presented with a testicular abscess, continuous with the epididymal head. Incision and drainage led to laboratory confirmation of tuberculous infection. He was treated with isoniazid, rifampicin, ethambutol, pyrazinamide and vitamin $B_{6}$ for 9 months, with good response. Despite meeting high-risk criteria for tuberculosis, our patient had a delayed diagnosis. We present the case and discuss the lessons learned.

\section{BACKGROUND}

Extra-pulmonary Mycobacterium tuberculosis infection often involves the genitourinary system, most frequently affecting the kidney and prostate. It is an unusual cause of acute scrotum.

To the best of our knowledge, this represents the first reported case in an immunocompetent patient in Australia, since 1942, of tuberculous epididymo-orchitis unrelated to intravesical BCG therapy.

It also illustrates some of the challenges of refugee health and serves as a timely reminder to consider atypical pathogens when caring for patients from developing nations.

\section{CASE PRESENTATION}

An 18-year-old boy, a refugee from Afghanistan, with no significant medical or family history, presented to our tertiary referral hospital after 1 day of severe left testicular pain. He denied trauma, other symptoms and sexual activity. On examination, the inferior pole of the left testis was exquisitely tender. Scrotal ultrasound (US) revealed heterogeneous change of the left epididymal tail with hypervascularity, suggesting the diagnosis of epididymo-orchitis (figure 1). He was discharged on a 2-week course of oral amoxicillin/clavulanic acid 875/125 mg twice daily.

Six weeks later, the patient re-presented after a week of malaise and a persistent tender left testis. Repeat US confirmed a $5 \times 3 \mathrm{~cm}$ left hemiscrotal abscess (figure 2). Incision and drainage in theatre was performed and he was discharged on a further 7-day course of dicloxacillin $500 \mathrm{mg}$ four times a day.

\section{INVESTIGATIONS}

Nucleic acid amplification, microscopy and culture from the theatre pus specimen revealed multisensitive tuberculosis (TB) infection. The patient subsequently underwent the following negative screening examinations; three consecutive early morning urine (EMU) microscopy culture and sensitivity (MC\&S) tests, HIV and hepatitis serology and chest $\mathrm{X}$-ray.

\section{DIFFERENTIAL DIAGNOSIS}

The initial diagnosis was epididymo-orchitis, presumed due to locally common bacterial pathogens. Despite a negative sexual history, this was assessed as the most likely means of transmission given the patient's young age. Failure of therapy and subsequently obtaining a tissue specimen led to the correct diagnosis of tuberculous epididymoorchitis.

\section{TREATMENT}

The patient was treated with isoniazid $300 \mathrm{mg}$, rifampicin $600 \mathrm{mg}$, ethambutol $1000 \mathrm{mg}$, pyrazinamide $1500 \mathrm{mg}$ and vitamin $\mathrm{B}_{6} 25 \mathrm{mg}$ once daily, with supervision to ensure compliance, for 9 months.

\section{OUTCOME AND FOLLOW-UP}

After completing treatment, the patient had a further three negative consecutive EMU microscopies, as while the initial negative EMUs decrease the sensitivity of this test, a later positive result post-treatment would have been an important

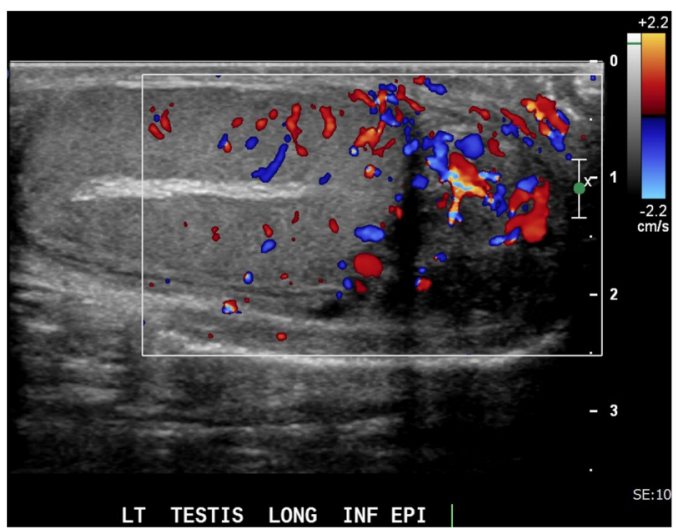

Figure 1 Ultrasound scan of left hemi-scrotum performed at first presentation. The lower portion of the left epididymis demonstrating slightly bulky heterogeneous change with increased blood flow. The left testis has normal echotexture and echogenicity. 


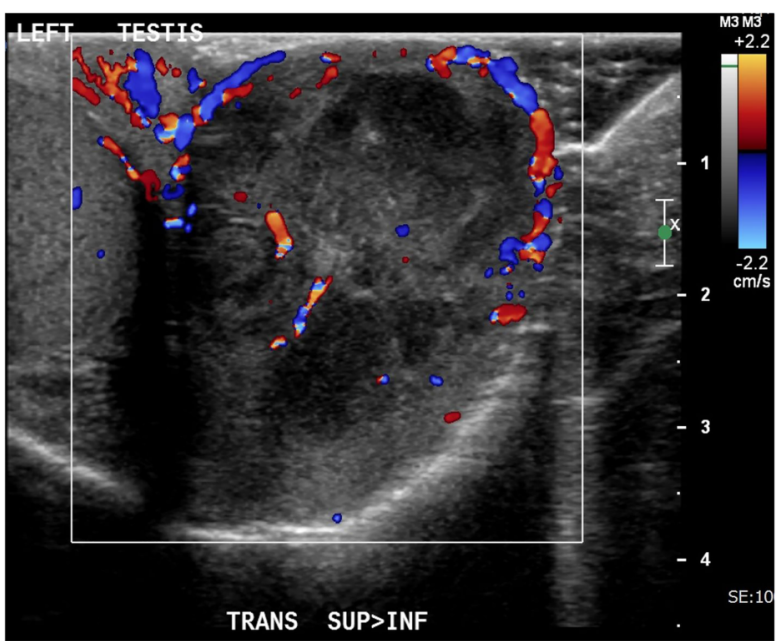

Figure 2 Ultrasound scan of left hemi-scrotum performed at second presentation. There is a well-circumscribed $32 \times 39 \times 45 \mathrm{~mm}$ collection in the inferior aspect of the left testis, containing heterogeneous, hypoechoic fluid, consistent with an abscess. This is continuous with the head of the epididymis, which is bulky, with surrounding significantly increased vascularity.

adverse finding. He remained asymptomatic, and clinical examination was normal both then and again at 15 months postdiagnosis, at which time he was discharged from the urology clinic.

\section{DISCUSSION}

Worldwide, the TB burden remains enormous, but with slowly decreasing incidence. In Australia, both burden and incidence are very low, however, the latter is increasing. This is principally related to migration, with $90 \%$ of new cases occurring in those born in other nations. ${ }^{1}$ Infection is frequently extra-pulmonary, involving the genitourinary system in $2-20 \%$ of cases, with the higher rates seen in developing nations. ${ }^{2}$ In Australia, genitourinary involvement occurs in $2 \%$ of TB cases. ${ }^{1}$ The kidney and prostate are most commonly affected. While less common, involvement of the scrotal organs is well known.

However, in Australia, there have been few reported cases of TB involving the testes or epididymides, with the last such case unrelated to intravesical BCG seen in the medical literature in $2009,{ }^{3}$ and further restricting cases to the immunocompetent, in 1942. ${ }^{4}$ However, we believe this represents under-reporting, with similar cases occasionally seen in commercial news media ${ }^{5}$ and by relevant health departments, according to $\mathrm{R}$ Stapledon (written communication, South Australian Tuberculosis Services, Royal Adelaide Hospital, Australia, 15 September 2014).

\section{Patient's perspective}

At first, the testicle got bigger and was sore. When I saw my GP he asked me to immediately go to the hospital. The doctors thought I would be okay after medication, but I had to go back a second time. Then I had an operation, which I thought I would get the first time.

- Afterwards, I had antibiotics for 9 months. More than 2 years later, the right testicle is still a bit bigger, although there is no pain. I was happy with the outcome.

\section{Learning points}

- The incidence of Mycobacterium tuberculosis infection is decreasing globally, but increasing in some developed nations, including Australia.

- Delayed diagnosis can occur when common presentations are caused by TB or other organisms uncommon to that anatomical site or country.

- Health professionals should consider atypical pathogens in at-risk populations, including patients who have spent time in developing nations and in those with treatment failure.

Acknowledgements The authors would like to acknowledge the contributions of Dr Bobby Goh and Mr Richard Wells in the preparation of this report.

Contributors NK and IH were involved in initial concept and manuscript drafting. $\mathrm{PC}$ and JB were responsible for manuscript reviewing and supervision.

Competing interests None declared.

Patient consent Obtained.

Provenance and peer review Not commissioned; externally peer reviewed.

\section{REFERENCES}

1 Bareja C, Waring J, Stapledon R, et al. National tuberculosis advisory committee. Tuberculosis notifications in Australia, 2010. Commun Dis Intell 2014;38:E36-48.

2 Figueiredo AA, Lucon AM. Urogenital tuberculosis: update and review of 8961 cases from the World literature. Rev Urol 2008;10:207-17.

3 Mansberg R, Nicholls M, Chan C, et al. Tuberculous epididymoorchitis presenting as pyrexia of unknown origin during acute myeloid leukaemia consolidation therapy. Intern Med J 2009:39:137-8.

4 Brown AE. Tuberculous epididymitis. Aust NZ JSurg 1942;12:79-80.

5 Virtual Medical Centre [Internet]. Subiaco WA; Virtual Medical Centre. Genital tuberculosis: Brad gets a crash course on his own testicles. 2010 Nov 25 [updated Mar 20 2014; cited 10 Sep 2014 ]. http://www.myvmc.com/experiences/ genitaltuberculosis-brad-gets-a-crash-course-on-his-own-testicles/

Copyright 2016 BMJ Publishing Group. All rights reserved. For permission to reuse any of this content visit

http://group.bmj.com/group/rights-licensing/permissions.

BMJ Case Report Fellows may re-use this article for personal use and teaching without any further permission.

Become a Fellow of BMJ Case Reports today and you can:

- Submit as many cases as you like

- Enjoy fast sympathetic peer review and rapid publication of accepted articles

- Access all the published articles

- Re-use any of the published material for personal use and teaching without further permission

For information on Institutional Fellowships contact consortiasales@bmjgroup.com

Visit casereports.bmj.com for more articles like this and to become a Fellow 